\title{
REFLECTING ON NINETY YEARS OF INTERMITTENT SUCCESS: THE EXPERIENCE OF THE SOUTH AFRICAN RESERVE BANK WITH INFLATION SINCE 1921
}

\author{
Jannie Rossouw ${ }^{1}$ and Vishnu Padayachee ${ }^{2}$
}

\section{ABSTRACT}

The South African Reserve Bank (the Bank) has achieved intermittent excellence in its quest to contain inflation since its establishment in 1921. This long experience highlights important experiences with inflation, which can be put to good use by central banks in other emerging-market economies. The conclusion is that there is no substitute for the long-run use of sound monetary policy in the quest to contain inflation.

Keywords: South African Reserve Bank, inflation, monetary policy

JEL classification: E42, E58, N27

\section{INTRODUCTION}

This paper considers the behaviour of inflation in South Africa since the establishment of the South African Reserve Bank (the Bank) in 1921.

1 SA Reserve Bank and Gordon Institute of Business Science (GIBS), University of Pretoria. Email: jannie.rossouw@resbank.co.za

2 School of Development Studies, University of KwaZulu-Natal; and Fellow, Stellenbosch Institute for Advanced Study (STIAS), Wallenberg Research Centre at Stellenbosch University, Marais Street, Stellenbosch 7600, South Africa. This paper draws on research used in the completion of the PhD thesis of Jannie Rossouw under the supervision of Professor Vishnu Padayachee at the School of Development Studies at the University of KwaZulu-Natal (see Rossouw 2008), and on Working Paper No. 50 of the School of Development Studies of the University of KwaZulu-Natal (see Rossouw and Padayachee 2008). The views and opinions expressed in this paper do not necessarily reflect the views and opinions of the SA Reserve Bank or any of the universities.

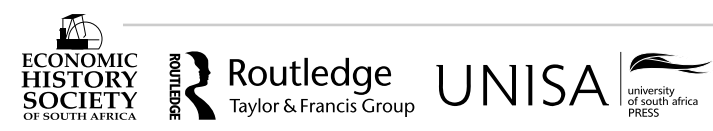


Comprehensive data on South African inflation dates back to $1921,{ }^{3}$ although rudimentary data on price level movements are available from well before 1921 . An analysis of this data shows that inflation became a persistent problem in South Africa from the late 1960s. Sustained annual double-digit inflation prevailed for 20 years from 1974 to 1993 (see for instance De Kock 1981; De Kock 1984; Republiek van Suid-Afrika 1985; Rupert 1974; Stals 1989; Stals 1996), although the country suffered earlier brief periods of inflation, e.g. during and after the two World Wars (see for instance De Kock 1954; Engelbrecht 1987, 29; Republiek van Suid-Afrika 1985; Rupert 1974; Stals 1989).

Over the period 1921 to 2010, average prices, as reflected by changes in the CPI, increased considerably in South Africa. In terms of an index with $1922=100$, the index value by 2010 was $12,122,2$, representing an average rate of inflation of some $5.6 \%$ per annum. The implication is that the purchasing power of R1,00 in 1921 is only some 1 cent today. Put differently, the price of an average basket of goods and services that sold for the equivalent of R1,00 in 1921, is about R112,00. For the review period covered by this paper, South Africa had the highest average rate of inflation (14.7\% per annum) between 1981 and 1990, which coincides with the decade in which the lowest rate of real annual economic growth (some 1.5\% per annum) was recorded ${ }^{4}$. As is shown in subsequent sections, the Bank had intermittent success in its quest to contain inflation since 1921.

This paper is structured as follows: Sections 2 to 8 consider developments in various periods since 1921 and the dominant policy approaches of the Bank in these periods. The conclusions follow in Section 9.

\section{GOLD STANDARD ERA: 1921 TO $1932^{5}$}

At its inception the initial policy objective of the Bank was to reintroduce the domestic gold standard at the pre-war conversion rate to the US dollar. Adverse economic developments during the Great War (as World War I was initially known) resulted in the suspension of the gold standard in South Africa after its suspension in the United Kingdom, with a concomitant inconvertibility of domestic currency for gold. This was viewed as a temporary aberration at the time.

The gold standard was reintroduced in South Africa on 18 May 1925. This followed on the recommendations of the Kemmerer-Vissering Commission of investigation into the desirability of reintroducing the gold standard in South Africa (Richards 1925, 559). Dr E.W. Kemmerer was at the time an economics measured by changes in the CPI since 1921.

4 A consideration of any possible trade-off between higher inflation and employment and/or economic growth as is intimated by the Phillips curve (see for instance Phillips 1958 or Samuelson and Solow 1960) is outside the scope of this paper. Except where stated otherwise, this section draws on De Kock 1954. 
professor as Princeton University and is remembered for his extensive work on advising governments, most notably in the Philippines and in South America (for instance Chile, Colombia, and Ecuador), on the establishment of central banks (Drake 1988, 141; Richards 1925, 559). Dr G. Vissering was at the time the Governor of the Dutch central bank (Richards 1925, 559).

As the United Kingdom (UK) returned to the gold standard on 25 April 1925 (Sloman 1994, 607), South Africa's domestic currency traded on par value with the British pound sterling from 18 May 1925. Sloman $(1994,607)$ criticises the reintroduction of the gold standard at the pre-war conversion rate in the UK, as this required the introduction of deflationary policies. The same was true in South Africa, but the decision was underscored at the time by "the general belief and conviction ... that exchange rate stability was of paramount importance for the maintenance of international confidence and the conduct of international trade" (De Kock 1956, 123).

The reintroduction of the gold standard was not sustainable in the UK, evidenced by its suspension on 21 September 1931 (De Kock 1956, 142) in an attempt to alleviate economic hardship in the midst of the Great Depression (see for instance Parkin 2003, 722 for background on the Depression). The South African authorities decided to retain the gold standard independently from the UK, thereby retaining convertibility of currency for gold and the free export and import of gold. This caused a capital outflow from South Africa and the Bank had to sell most of its foreign currency holdings in order to meet the demand for gold (through currency conversion). The Bank recorded a loss of some $£ 1.5$ million on these transactions, which exceeded its reserves built up over the preceding 10 years by some $£ 400,000$. This loss had to be written down against its capital fund of $£ 1$ million. As the Bank had to publish a weekly statement of assets and liabilities at the time, rather than a monthly statement as is currently the case, these mounting losses received considerable public attention.

The decision to maintain the gold standard in South Africa not only exacerbated the consequences of the Great Depression, but the losses suffered by the Bank on gold transactions also raised questions about the Bank's financial sustainability. In view of these concerns, the Minister of Finance issued a statement by the end of October 1931, confirming a government guarantee of the Bank's solvency and liquidity. In view of the operational autonomy that many central banks, including the Bank, enjoy today, a statement of this nature places such autonomy in serious jeopardy. If a central bank is no longer financially viable, it can hardly be argued that it should have the autonomy to conduct it operations without interference. The government will have every right to insist on steps limiting its financial exposures emanating from the operations of the central bank.

As virtually all sectors of the South African economy (other than gold mining which benefited from a higher international price) suffered hardship owing to the decision to maintain the gold standard, it contributed to depressed domestic economic conditions. The gold standard controversy therefore developed into a 
political matter, as the government favoured its maintenance, while the opposition favoured its abolition (SA Reserve Bank 1971, 34). The matter came to an unexpected conclusion in December 1932, with the announcement on 21 December that a viable alternative political party would be established with the sole goal of seeking the abolition of the gold standard. As it was expected that the new political party could unseat the government and abolish the gold standard, a renewed demand for gold emerged. This forced the government to abolish the gold standard (and therefore the convertibility of currency into gold) on 28 December 1932 (SA Reserve Bank 1971, 37). Inconvertibility was seen as a temporary measure at the time. South African banknotes continued to carry a nominal promise of convertibility until 1992 (Van Rensburg 2003, 295).

Looking back on the gold standard controversy from the perspective of 2011, the speed at which some (but not all the important) decisions were taken is somewhat surprising. Within seven days after the announcement of 21 December 1932, the gold standard was abolished. In view of this speedy abolition, it is inexplicable that no clear policy framework, as is explained in the next section, was announced at the time of the abolition of the gold standard.

South Africa experienced deflation from 1921 to 1932, as is shown in Tables A1 and B1 in Appendices A and B. During this period, prices declined on average by some $3.3 \%$ per annum, but with a very sharp decline of $4.5 \%$ in 1932 . This was therefore considered a period of moderate deflation, which had developed into depression-like conditions by 1932. It can be argued that the Bank initially achieved its objective of mild deflation in the wake of restoring the gold standard at the pre-war conversion rate. However, the policy stance of the Bank (i.e. to maintain the gold standard) eventually contributed to prolonging the Great Depression, rather than ending it.

\section{AFTER THE GOLD STANDARD: 1933 TO $1938^{6}$}

After the abolition of the gold standard, the monetary authorities ${ }^{7}$ took the inexplicable decision "to leave the future monetary policy of the country to be determined by Parliament" (De Kock 1954, 191), due to reconvene early in 1933. Today this would be viewed as abandoning responsibility for policy formulation and implementation by the relevant authorities, and would certainly not go unchallenged. Given the haste and speed at which the gold standard was abolished, it is somewhat surprising that the same efficiency was not displayed in deciding on a future policy framework. The Currency and Exchanges Act, Act No. 9 of 1933, passed in March 1933 by Parliament, linked the value of the domestic currency to that of pounds sterling. This implied that South Africa joined the Sterling Area.

6 Except where stated otherwise, this section draws on SA Reserve Bank 1971.

7 The Treasury (as it was known at the time) and the SA Reserve Bank. 
Domestic economic activity benefited from the abolition of the gold standard, as South African exports became more competitive internationally (see for instance De Kock 1954, 212). The general improvement in economic conditions gave rise to the question whether the Bank would be able to control inflation, as abundant domestic liquidity made it unnecessary for commercial banks to borrow from the Bank. The focus of central banks increasingly moved to the control of credit to stabilise price levels after the abolition of the gold standard (De Kock 1956, 123).

In the case of South Africa the Bank's legislation made provision for a clear price level objective only since the promulgation of the SA Reserve Bank Act, Act No. 90 of 1989, but a literature review shows that the Bank had focused on mitigating inflation well before 1989 (see for instance De Kock 1954; De Kock 1956; SA Reserve Bank 1971). Initially Section 3 of this Act stated as the Bank's objectives:

[i]n the exercise of its powers and the performance of its duties the Bank shall pursue as its primary objectives monetary stability and balanced economic growth in the Republic, and in order to achieve those objectives the Bank shall influence the total monetary demand in the economy through the exercise of control over the money supply and over the availability of credit.

This was changed in 1996 to "[t]he primary objective of the Bank shall be to protect the value of the currency of the Republic in the interest of sustainable economic growth in the Republic". This objective is aligned to the Constitution, Act No. 108 of 1996, which states in Section 224 as the primary object of the Bank its duty "to protect the value of the currency in the interest of balanced and sustainable economic growth in the Republic".

Prices increased on average by $0.6 \%$ per annum between 1933 and 1938. Despite the Bank's problems with restricting credit, it achieved the maintenance of stable prices.

\section{THE STERLING AREA: 1939 TO $1960^{8}$}

At the outbreak of World War II, South Africa retained its membership of the Sterling Area, ${ }^{9}$ established in 1933 after the abolition of the gold standard. Domestically monetary policy was supplemented not only by exchange control, but also by an extensive system of direct control measures to curb inflationary pressures during the War. Owing to these extensive controls, South Africa experienced suppressed demand, rather than actual inflation (De Kock 1954, 268). As is often the case with suppressed demand, domestic inflation also increased

8 Except where stated otherwise, this section draws on De Kock 1954 and SA Reserve Bank 1971.

9 Exchange control measures imposed in 1939 in terms of the Sterling Area arrangement permitted free payment flows between member countries, but payments to countries outside the Area required exchange control approval. This arrangement forms the cornerstone of South Africa's subsequent exchange control dispensation. 
substantially in South Africa after the relaxation of controls when the War ended (see for instance Kosters 1977, 121, 122, and 188).

South Africa had emerged with a generally sound domestic economy from the War. The monetary policy framework rested, inter alia, on the principle of stable exchange rates, introduced in terms of the Bretton Woods system (Republic of South Africa 1985, 144) of fixed but adjustable exchange rates, introduced after the War.

In 1949 the National Finance Corporation (NFC), a subsidiary of the Bank (Republiek van Suid-Afrika 1985, 113; see also De Kock 1956, 171), was established with the purpose of developing a domestic money market and to ensure optimal utilisation of domestic capital. The liquidity of the NFC was guaranteed by the Bank in terms of an agreement that its Treasury bills will be discounted as and when required, at the rate at which the NFC acquired the bills.

In the 1950s South Africa adopted:

a form of conservative Keynesianism which contained important elements of what later came to be known as monetarism. This was evident, for example, from the important role assigned to the money supply ... [although] ... no thought was given during this phase to setting either published or unpublished targets for M1, M2, cash base or any other monetary aggregate. (Republic of South Africa 1985, 144)

In terms of the Bretton Woods arrangements, exchange rate stability enjoyed a high priority among the goals set for monetary policy.

Over the period 1939 to 1960 inflation was at an average annual rate of about $3.8 \%$ per annum, although price pressures were on occasion suppressed by direct control measures, with the implication that the official rate of inflation was not always a true reflection of inflationary conditions in the economy.

\section{EXCHANGE AND OTHER DIRECT CONTROL MEASURES: 1961 TO $1980^{10}$}

When the country became the independent Republic of South Africa on 31 May 1961 it left not only the Commonwealth but also the Sterling Area. A new decimal currency system with R2 $=£ 1$ was introduced on 14 February 1961, replacing the previous system comprising pounds, shillings and pennies $(£ / s / d)$. In the wake of political instability following on the Sharpeville riots on 21 March 1960 (see for instance Reeves, n.d.), South Africa experienced large foreign capital outflows to countries within the Sterling Area that could not be covered by the small current account surplus on the balance of payments.

10 Except where stated otherwise, this section draws on Republic of South Africa 1985 and SA Reserve Bank 1971. 
Exchange control measures, introduced initially in terms of the Sterling Area arrangement, were expanded and adopted for South Africa's unique circumstances at the time. Restrictions were placed on all financial flows from South Africa, i.e. limiting foreign investment by residents and the repatriation of the sales proceeds of domestic assets by non-residents through a securities rand system. The securities rand system evolved over time into the financial rand system, which became the cornerstone of a system of exchange control over nonresidents. Extensive exchange controls implied that residents could not protect themselves against domestic inflation by means of divestment from South Africa.

By the middle of the 1960s the Bank introduced the use of credit controls, credit ceilings and deposit rate control as monetary policy measures designed to limit credit demand (SA Reserve Bank 1971, 66). This was supplemented in July and August 1966 by fiscal measures aimed at curbing demand, the relaxation of import control and stricter monetary policy (SA Reserve Bank 1971, 67).

By 1960 countries were using the Bretton Woods system of fixed (but adjustable) exchange rates, with the US dollar serving as anchor for the exchange rate system, as it was convertible into gold at a fixed price of US\$35/oz (Mohr and Fourie 2004, 436). With inflationary pressures developing in the US in the wake of the Vietnam War, the system collapsed in 1971. Major industrialised countries introduced a system of floating exchange rates and South Africa pegged its exchange rate - albeit at varying levels after formal devaluations in December 1971 and in September 1975, initially to UK pound sterling, then to the US dollar, then a peg to a basket of currencies, and again to the US dollar - before a system of managed floating was introduced from January 1979.

Despite direct control measures, domestic inflation started accelerating from low levels in 1968 and reached double-digit figures by 1973, although the annual rate of inflation moved to double digits only by 1974. This accelerating trend in inflation was exacerbated by the 1973 oil price shock. International oil prices increased sharply in the aftermath of the "Six Day" war between Israel and neighbouring countries. This resulted in a sharp increase in the domestic fuel price which, in turn, resulted the development of a domestic cost-push inflation spiral. South Africa was not the only country to suffer accelerating inflation as a result of the oil price shock, but it took much longer to get domestic inflation under control than was the case in South Africa's major trading partner countries.

The average rate of inflation was about $6.6 \%$ over this period, although it accelerated sharply towards the end of the period. Monetary policy did not achieve the objective of stable prices. This is evidenced, inter alia, by the fact that the Council of the Economic Society of South Africa arranged a conference on the country's inflation problem for 24 and 25 August 1967 (Richards 1967, 278). The conference proceedings report a debate on the description of the type of inflation suffered by South Africa in the late 1960s (see for instance Du Plessis 1967, 365; Samuels 1967, 341; Van der Horst 1967, 323). Hobart Houghton stated that "[t]he main strength of the inflation of our time was that we expected it to continue" (1967, 292). This view was supported by Samuels, who stated that 
"once the market's expectations ... are broken, the problems of the transition to a non-inflationary era will become progressively easier. The eradication of inflationary expectations will not be easy" $(1967,355)$. When we reflect on this conference some 40 years later, our reaction is that the issues remain the same, only the names of the conferences considering them have changed.

Market-oriented monetary policy replaced direct controls from 1 September 1980. Although this change in policy approach is associated with the appointment of Dr G.P.C. de Kock as Governor with effect from 1 January 1981, it was announced by the retiring Governor, Dr T.W. de Jongh, at the Bank's 60th ordinary meeting of stockholders held on Tuesday, 26 August 1980 (De Jongh 1980, 10). Despite periodic amendments to the domestic monetary policy framework since 1980, the Bank has not departed from the principle of marketoriented monetary policy.

\section{STUBBORNLY HIGH INFLATION: 1981 TO $1989^{11}$}

The Bank's monetary policy approach in early 1980s is described by Casteleijn as a "mixed system during transition" (2001, 5; see also Nel 1993, 120), while Gidlow $(1995,4)$ describes this period as a market-oriented mixture of conservative Keynesian demand management and monetarism, with the focus on discretionary demand management.

This period is characterised by a number of important events, some of which impacted negatively on the conduct of monetary policy in South Africa. First, the financial rand, which replaced the securities rand as the cornerstone of exchange control over non-residents, was abolished in February 1983, and with it virtually all exchange controls over non-residents (Republic of South Africa 1985, 131). This implied that non-residents could disinvest from South Africa and repatriate their proceeds abroad to any jurisdiction for the first time in many years.

Secondly, in terms of the political dispensation of constituencies with elected Parliamentary representatives used in South Africa at the time, the ruling party faced a crucial by-election in the Primrose constituency on Thursday, 29 November 1984. Interest rates were at a new record-high level from August 1984 (the prime overdraft rate was at 25\%) (SA Reserwebank 1985, 26), resulting in domestic unhappiness about economic conditions and monetary policy.

The Bank dropped interest rates ten days before the by-election (SA Reserve Bank 1984, 13 and 14) and increased rates to their previous level on 8 January 1985 (SA Reserve Bank 1985, 16). Although the Bank denied at the time that these movements in rates were politically induced, it was stated in the media that:

there is no escaping the fact that ... [the] ... cut in prime interest rates was most likely the opportunity cost of the National Party winning the Primrose by-election. Despite Reserve

11 Except where stated otherwise, this section draws on Stals 1996. 
Bank Governor Gerhard de Kock's firm denial, this obvious political manoeuvre has all the signs of a quick fix ... (Financial Mail 1984, 35)

This incident eroded the ability of the Bank to conduct credible monetary policy and reminds of a political business cycle, i.e. the alignment of policy decisions with election cycles (Nordhaus 1975).

Thirdly, South Africa's balance-of-payments situation deteriorated substantially after the Rubicon ${ }^{12}$ speech of Mr P.W. Botha, the President of the country at the time, on 15 August 1985 (see for instance Finweek 2006, 21), as expectations of major political changes to be announced in the speech did not materialise. The domestic economic outlook deteriorated after the speech, as it caused not only a substantial outflow of foreign capital from South Africa, but also a withdrawal of foreign credit lines previously available to the country. As a result of these "financial sanctions" against South Africa, domestic borrowers were unable to refinance their foreign short-term borrowing.

The situation deteriorated to such a degree that the temporary closure of the foreign exchange markets was announced on 28 August 1985. This was followed by the announcement of a moratorium on the repayment of a large portion of South Africa's foreign debt and the reintroduction of exchange control over nonresidents (i.e. the reintroduction of the financial rand) on 1 September 1985. This was followed by a rescheduling of the repayment of South Africa's foreign debt, with the final tranche of rescheduled debt repaid only on 15 August 2001 (Mboweni 2001).

Fourthly, the final report of The Commission of inquiry into the monetary system and monetary policy of South Africa, chaired by Dr G.P.C. de Kock (the De Kock Commission) was published in 1985 (Republic of South Africa 1985). For the purpose of this paper it is of interest to note that the Commission states that the intention of the legislator in establishing the Bank was:

[t]o ensure the Bank's independence and particularly its freedom from party political pressure. In this respect the Commission has found no evidence that the intentions of the legislator have not been realised. The Bank jealously guards its reputation for objectively formulating and applying monetary policy in the interest of the whole community. (Republic of South Africa 1985, 253)

In view of the Primrose prime incident described above, this statement seems to imply that the commissioners had either selective memory or no memory at all.

12 As Mr Botha made reference in the speech to the proverbial crossing of the Rubicon, it subsequently became known as the Rubicon speech. This was a reference to Julius Caesar's crossing of the Rubicon river in 49 BC. The phrase 'crossing the Rubicon' has survived to refer to any person committing irrevocably to a risky course of action (Encyclopaedia Britannica 2005). In the event of the infamous Rubicon speech this course of action was interpreted as entrenching an unacceptable political system, rather than introducing long-overdue political change (Tambo 1985). 
In respect of the autonomy of the Bank, the Commission recommended that "[w]hile the Reserve Bank and the Treasury acting together as the monetary authorities should jointly share the responsibility for broad monetary policy ... the Reserve Bank ... should primarily be charged with the responsibility for maintaining monetary stability and protecting the internal and external value of the currency" (Republic of South Africa 1985, 253). This quotation raises two important issues:

1. the Commission propagated the notion of the monetary authorities with joint responsibility for monetary policy decisions. Subsequently a clearer understanding of a splitting of responsibilities for monetary policy has emerged, in terms of which the government (or the Minister of Finance) sets, or sets jointly with the central bank, the monetary policy goal, while the central bank is granted the necessary operational independence to achieve the agreed goal; and

2. the Commission's recommendation was that the Bank "should primarily be charged with ... protecting the internal and external value of the currency" (Republic of South Africa 1985, 253). When the Bank adopted a mission statement for the first time in 1990, it stated as the Bank's primary aim the protection of the internal and external value of the rand. This objective, albeit in revised format (protect the value of the rand) is also entrusted to the Bank by the Constitution of South Africa, Act No. 108 of 1996.

It was announced early in 1986 that the government had accepted the recommendations of the De Kock Commission, which implied, inter alia, that the Bank would set specific growth targets for a money supply aggregate (Du Plessis 1986). The Bank adopted broadly-defined M3 money supply as the aggregate to be used for targeting purposes and elected to introduce low-profile, adjustable growth targets, rather than fixed targets.

Lastly, this period is also characterised by a problem similar to the Primrose prime incident, although it has not received as much publicity as the Primrose incident. In terms of government's 'Proposed Action Plan for Combating Inflation' introduced in 1988 (Stals 1989, 10), inflation had to be contained by means of a broad spectrum of measures which included restraint in government expenditure. This policy was supported by an implicit understanding that wages and all-important prices in the economy would not be increased - in practice therefore a low-key incomes policy approach. Important prices earmarked for no increase included interest rates. Gidlow states that the discretionary policy followed by the Bank at the time:

can be conducted more effectively in an environment where a central bank enjoys full independence. This was not the case in 1988 for instance when the monetary authorities experienced difficulties in pushing interest rates higher at a time when the balance of payments position and inflationary pressures were worsening. Indeed, this problem manifested itself on several occasions during the 1970s and 1980s, and was associated with 
the difficulties faced by the authorities in conducting monetary policies when international financial shocks occurred. (Gidlow 1995, 9)

Over this period inflation was at an average annual rate of about $14.7 \%$. An ex post analysis of this period leaves the impression that the Bank followed an inflation target of between 10 and $15 \%$ per annum, with monetary policy tightening whenever inflation breached $15 \%$, and monetary policy relaxation whenever inflation declined to levels around $10 \%$. This was, however, not the result of a deliberate policy approach, but rather the result of inconsistent policy application. The Bank all along had the tools and knowledge to contain inflation, but failed to apply consistent policies to achieve this goal. It is no surprise, therefore, that the final pronouncement on this period in the Governor's Address of 1989 states that inflation was not regarded as the country's main economic problem in the 1980s (Stals 1989, 9).

\section{CONQUERING INFLATION: 1990 TO $1999^{13}$}

After the difficulties of the previous decade, containing inflation was announced as the focus of monetary policy on 29 August 1989, at the occasion of the Bank's 69 th ordinary general meeting of shareholders. ${ }^{14}$ Dr C.L. Stals was appointed Governor shortly before this meeting and recommitted the Bank to containing inflation by stating that:

the main emphasis of monetary policy has ... [now] ... been switched to the curtailment of inflation ... [i]n the circumstances it can no longer be regarded as appropriate to continue to accommodate price increases through large increases in Bank credit and in the monetary policy ... [as] ... [t] $]$ hrough a disciplined monetary and fiscal policy approach ... it will be possible to reduce the rate of inflation in South Africa over the next few years. (Stals 1989, 10)

This change in policy focus resulted in a time inconsistency problem (see for instance Barro and Gordon 1983a; Barro and Gordon 1983b; Kydland and Prescott 1977) in South Africa, particularly in view of the earlier Primrose prime incident. Padayachee $(2001,753)$ states that the Bank had no real autonomy before 1989, which contributed to the lack of credibility of its policy actions even after the clear recommitment of the new Governor to conquering inflation. This lack of credibility contributed to three years of stagflation in South Africa, characterised by negative economic growth rates and double digit inflation. Sound monetary policy only started bearing fruit by 1993 , when a general declining trend in inflation showed price increases could be contained to levels commensurate

13 Except where stated otherwise, this section draws on Van der Merwe 1999.

14 This was the first meeting of shareholders of the Bank, introduced by the SA Reserve Bank Act of 1989. Previous legislation made reference of stockholders of the Bank. 
with that of South Africa's major trading partner countries. The reestablishment of the autonomy and independence of the Bank is evidenced, inter alia, by the fact that interest rates were not reduced at the time of the first democratic elections in April 1994, or before subsequent general elections.

Exchange rate stabilisation was one of the cornerstones of the monetary policy approach in this period. The Bank intervened actively in the foreign exchange market to achieve this objective, as currency depreciation resulted in domestic inflation. In its attempts to achieve exchange rate stability, the Bank made extensive use of an oversold foreign exchange position (the net oversold foreign exchange position, or NOFP). The NOFP was expunged only after the Bank abandoned its focus on the exchange rate.

As money supply targeting lost its usefulness domestically and internationally as an anchor for monetary policy (Casteleijn 2001, 6; Rossouw 2005), South Africa gradually moved to the adoption of eclectic monetary policy in 1996 (Van der Merwe 1997, 2). Bank rate was replaced by the repurchase (repo) rate on 13 March 1998 (Van der Merwe 1997, 2 and 3). Although the repo rate is still in use, it was initially introduced as a variable rate in terms of which the Bank could signal its monetary policy stance to the market. As the variable repo rate did not respond satisfactorily to the Bank's signals on a number of occasions, it was changed to a fixed rate system subject to adjustments by the Bank towards the end of 1999.

In March 1998 the Bank announced its intention to align domestic inflation with the inflation rates of South Africa's major trading partner countries. Sources differ about the level of this informal "target", e.g. 1 to $5 \%$ (see for instance Casteleijn 2001, 6) or 4.5\% (see for instance Rossouw 2005). The main disadvantage of this informal "target" was that "it could not be expected to elicit the same commitment to policy co-ordination that would follow if the government had formally endorsed or set the target" (Casteleijn 2001, 6). Khabo states that "while Chris Stals was successful in fighting inflation, he was accused of lack of transparency" (2002, 151).

After democratic elections in 1994 a policy of gradually abolishing exchange control was adopted. With a new political dispensation and sound monetary policy, it was less necessary to rely on exchange control to protect the domestic economy against the negative consequences of bad policy decisions or negative political perceptions. In 1995 the financial rand was abolished, implying that the only remaining exchange controls on non-residents were limits pertaining to their local borrowing capacity. This was followed by the gradual relaxation of exchange control on domestic juristic persons and residents, which included an exchange control amnesty for residents (other that juristic persons). Nearly 43,000 individuals applied for amnesty, which implies that nearly 1 out of every 1,000 South Africans had illegal assets amounting in total to some R45 billion abroad, despite the application of strict exchange control restrictions over residents since 1961 (Rossouw 2008). The amnesty showed that the exchange control system can hardly be described as a success. 
Over the period 1990 to 1999 the average annual rate of inflation was about $9.9 \%$. However, as inflation started off at a level of $14.4 \%$ per annum, the trend in inflation rather than its average level, is a better indication of the success of monetary policy over this period.

\section{CONTAINING THE CONQUERED: TARGETING INFLATION SINCE $2000^{15}$}

South Africa adopted formal inflation targeting as a monetary policy framework on 23 February 2000 (see Manuel 2000 in this regard). This monetary policy framework had been adopted for the first time in New Zealand in 1990, and gained popularity in subsequent years. By the middle of 2010 it was used by 24 countries (see for instance Allen, Baumgartner, and Rajan 2006, 5; Kopits 2008, 78). Inflation targeting confirms a commitment to a rules-based monetary policy framework which limits the scope for time inconsistency problems in the implementation of monetary policy.

Since the adoption of inflation targeting in South Africa, the specification of the target has been revised from time to time. The target was initially specified in terms of changes in the CPIX, which was defined (in a somewhat cumbersome fashion) as changes in the CPI for metropolitan and other urban areas excluding changes in mortgage interest cost (Mboweni 2005; see also Van der Merwe 2004). The target range was initially set as 3 to $6 \%$ for achievement by 2002, as monetary policy adjustments normally take between 18 and 24 months to influence the rate of inflation.

Adopting an inflation target implied that the Bank abandoned other monetary policy objectives in favour of this policy objective. The International Monetary Fund states that inflation targeting implies a commitment to "a unique numerical target in the form of a level or a range for annual inflation" (International Monetary Fund 2005, 161-162). This implied the abolition of any exchange rate target for the currency. The Bank stopped intervention in the foreign exchange market and merely purchases foreign exchange to supplement is foreign exchange reserve holdings.

In 2001 it was announced that the initial target of 3 to $6 \%$ would be retained for 2003, but be reduced to 3 to 5\% for 2004 and 2005 (Manuel 2001, 6). In 2002 it was announced that the target for 2004 and 2005 were revised to 3 to $6 \%$ in reaction to domestic and international economic instability, and would be retained at that level until further notice (Manuel 2002, 4). It was announced in 2003 that the inflation target should be regarded as a continuous target to be achieved on a monthly basis, while it was previously viewed as an average annual target (Manuel 2003, 6). Owing to a revising of the South African CPI which replaced the use of 
mortgage interest cost with imputed rent in the calculation of owner-occupied housing, it was announced in October 2008 that the Bank would target changes in the CPI from January 2009 (Statistics SA 2008).

The South African government selected a target range, rather than a specific point, for the country. While the advantage of a single point inflation target is that it provides a clear focus on the particular rate of inflation, it "implies a degree of precision which cannot realistically be expected of monetary policy, especially in a small, open economy" (Casteleijn 2001, 8). Of the 24 countries identified as inflation targeters, three use a single target point with no range, while 11 countries use a single target point with a range around the single point. The remaining ten countries use a target range. The specification of the CPI used for targeting purposes and the inflation target should be aligned. With a broad specification of the rate of inflation used for targeting purposes in South Africa (changes in the CPI with no exclusions) a target range should be used to cater for the many price changes that influence the rate of inflation.

The preceding discussion shows that the South African government sets and adjusts the inflation target. This implies that the Bank does not have goal independence in its conduct of monetary policy, but operational independence in as much as it can elect the use of any available monetary policy instruments in the pursuit of the target.

The average inflation rate since the adoption of inflation targeting (up to the middle of 2010) was, at about $6.2 \%$ per annum, marginally above the target range. Inflation moved in this period between a low point of $1.4 \%$ in 2004 and a high point of $11.5 \%$ in 2008 .

\section{A FINAL REFLECTION ON NINETY YEARS OF INTERMITTENT SUCCESS}

Since the establishment of the Bank in 1921, South Africa has experienced intermittent success in containing or conquering inflation. The Bank was remarkably successful in containing inflation up to the 1960, although inappropriate policies were followed on occasion. Domestic inflation accelerated from 1968 and in the ensuing years the Bank seemed incapable of controlling it effectively. The problem of accelerating inflation was exacerbated by the international oil price shock of 1973. A reflection on the period 1974 to 1993 shows that the Bank was one of very few central banks internationally that managed to contain inflation between $10 \%$ and $20 \%$ per annum, without runaway inflation developing.

As a result of cumulative inflation since 1921, the South African CPI increased from 100 in 1922 to 12,170,6 by 2010. This represents an average rate of inflation of some 5.6\% per annum. In the United Kingdom (a country which had close ties with South Africa for most of the review period), the CPI increased from 100 in 1921 to about 3,600 in 2010, for an average rate inflation of inflation of 
some $4.1 \%$ per annum. Over the same period the CPI in the United States of America increased from 100 to about 1,220 in 2010, for an average rate of inflation of some $2.9 \%$ per annum. This comparison reconfirms that the Bank had intermittent success in containing inflation.

The Bank's current rules-based monetary policy framework anchored in inflation targeting places South Africa squarely in the realm of orthodox policy and the Washington Consensus. The emergence of a Post-Washington Consensus (see for instance Padayachee 2001, 746) gives rise to the question whether the Bank will retain an inflation targeting monetary policy framework. However, any decisions to amend the framework or change the policy can only be taken by the South African government.

The assessment in this paper shows that:

- there is no substitute for sound monetary policy (as is indeed true in the broader sense in respect of all economic policy) in containing inflation; and

- monetary policy approaches should be discarded and replaced by more suitable policy frameworks whenever circumstances change. In certain instances (particularly the gold standard used until 1932) monetary policy was not changed in a timely fashion. This is an important lesson for central banks in emerging-market economies, as such countries are often more constrained options by political considerations in their monetary policy than developed countries.

The Bank should continue to conduct sound monetary policy in the interest of sustained low inflation. Inflation is ungood and cannot be used as a policy instrument to achieve economic or political objectives. Monetary policy retaining an overarching focus on containing inflation should be a characteristic of the next decade to the Bank's centenary celebration on 30 June 2021.

\section{REFERENCES}

Allen, M., U. Baumgartner, and R. Rajan. 2006. Inflation targeting and the IMF. Washington: International Monetary Fund.

Barro, R., and D. Gordon. 1983a. A positive theory of monetary policy in a natural rate model. Journal of Political Economy 91, no. 4: 589-610.

Barro, R., and D. Gordon. 1983b. Rules, discretion and reputation in a model of monetary policy. Journal of Monetary Economics 12, no. 1: 101-121.

Casteleijn, A. 2001. South Africa's monetary policy framework. Paper presented at the conference on monetary policy frameworks in Africa, SA Reserve Bank, Pretoria, South Africa, 17-19 September 2001.

Constitution. 1996. No 108 of 1996.

Currency and Banking Act. 1920. No 31 of 1920, as amended.

De Jongh, T.W. 1980. Governor's address. Address at the 60th ordinary general meeting of stockholders: Pretoria, South Africa. 26 August. 
De Kock, G. 1954. A history of the South African Reserve Bank (1920-52). Pretoria: J.L. van Schaik.

De Kock, G. 1981. Governor's address. Address at the 61st ordinary general meeting of stockholders: Pretoria, South Africa. 25 August.

De Kock, G. 1984. The "mix" of monetary and fiscal policy, address to the Financial Mail Investment Conference: Johannesburg, South Africa. 16 November.

De Kock, M.H. 1956. Central Banking. 3rd ed. London: Staples Press Limited.

Drake, P.W. 1988. The money doctor in the Andes: The Kemmerer missions 1923 to 1933. Durham, NC: Duke University Press.

Du Plessis, B.J. 1986. Budget speech. National Treasury: Pretoria, South Africa. 17 March.

Du Plessis, F.J. 1967. Opsomming van meningsverskille van die konferensie. Suid-Afrikaanse Tydskrif vir Ekonomie 35, no. 4: 365-366.

Encyclopaedia Britannica. 2005. Encyclopaedia Britannica Premium Service. USA: Encyclopaedia Britannica, http://www.brittannica.com/eb/article-9047255

Engelbrecht, C.L. 1987. Geld in Suid-Afrika. Tafelberg Uitgewers: Kaapstad.

Financial Mail. 1984. Hallucinations now, reality later. 23 November, 35-38.

Finweek. 2006. Bylae oor die Suid-Afrikaanse Reserwebank. 21 September, 3-30.

Gidlow, R.M. 1995. Monetary policy under Dr Gerhard de Kock: 1981-1989. Pretoria: SA Reserve Bank.

Hobart Houghton, D. 1967. Second discussant of a paper by L.M. Lachmann, Causes and consequences of the inflation of our time. South African Journal of Economics 35, no. 4: 291-292.

International Monetary Fund. 2005. World Economic (IMF) Outlook. September.

Khabo, V.S. 2002. An evaluation of the impact of monetary policy on a small and open economy: The case of the Republic of South Africa. DCom diss., University of Pretoria.

Kopits, G. 2008. Inflation targeting under stress. Central Banking 19, no. 2: 76-80.

Kosters, M.H. 1977. Controls and inflation: An overview. In An analysis of inflation, ed. J. Popkin, Cambridge, MA: Ballinger.

Kydland, F.E., and E.C. Prescott. 1977. Rules rather than discretion: The time inconsistency of optimal plans. Journal of Political Economy 85, no. 3: 473-491.

Manuel, T.A. 2000. Budget speech by the Minister of Finance. National Treasury: Pretoria. 23 February.

Manuel, T.A. 2001. Medium-term Budget Policy Statement. National Treasury: Pretoria, South Africa. 30 October.

Manuel, T.A. 2002. Medium-term Budget Policy Statement. National Treasury: Pretoria, South Africa. 29 October.

Manuel, T.A. 2003. Medium-term Budget Policy Statement. National Treasury: Pretoria, South Africa. 12 November.

Mboweni, T.T. 2001. Governor's address, address at the 81 st ordinary general meeting of shareholders: Pretoria, South Africa. 28 August.

Mboweni, T.T. 2005. Statement of the Monetary Policy Committee, SA Reserve Bank, Pretoria, 10 February, available at: http://www.reservebank.co.za/

McAleese, D. 2004. Economics for business: Competition, macro-stability and globalisation. 3rd ed. Essex: FT Prentice Hall. 
Mohr, P., and L. Fourie, eds. 2004. Economics for South African students. 3rd ed. Pretoria: Van Schaik.

Nel, H. 1993. Die monetêre beheermeganisme in Suid-Afrika. D Comm proefskrif, Universiteit van Port Elizabeth.

Nordhaus, W.D. 1975. The political business cycle. Review of Economic Studies 42, no. 2: 169190.

Padayachee, V. 2001. Central bank transformation in a globalized world: The Reserve Bank in post-apartheid South Africa. Journal of International Development 13, no. 6: 741-765.

Parkin, M. 2003. Economics. 6th ed. USA: Addison-Wesley.

Phillips, A.W.H. 1958. The relation between unemployment and the rate of change of money wage in the United Kingdom: 1861 to 1957. Economica 25, no. 100: 283-299.

Reeves, A. n.d. The Sharpeville massacre: A watershed in South Africa. Available at: http://www. anc.org.za/ancdocs/history/misc/shareve.html

Republic of South Africa. 1985. The Commission of inquiry into the monetary system and monetary policy of South Africa (De Kock Commission). First interim report: RP 112/ 1978, Second interim report: RP 93/1982, and Final report: RP 70/1984. Pretoria.

Republiek van Suid-Afrika. 1985. Die Kommissie van ondersoek na die monetêre stelsel en monetêre beleid in Suid-Afrika (De Kock-kommissie). Eerste tussentydse verslag: RP 112/ 1978, Tweede tussentydse verslag: RP 93/1982, en Finale verslag: RP 70/1984. Pretoria.

Richards, C.S. 1925. The Kemmerer-Vissering Report and the position of the Reserve Bank of the Union of South Africa. The Economic Journal 35, no. 140: 558-567.

Richards, C.S. 1967. Comment on Professor Samuels' paper and inflation generally. South African Journal of Economics 35, no. 4: 358-359.

Rossouw, J. 2005. Monetêre beleid in Suid-Afrika sedert 1965: Die vordering vanaf direkte beheer tot inflasieteikens. Tydskrif vir Geesteswetenskappe 45, no. 2: 292-300.

Rossouw, J. 2007. Communication supporting an inflation-targeting monetary policy regime: The case of the South African Reserve Bank, paper presented at the 18th International Conference of SPACE, Nicosia, 21-24 March 2007.

Rossouw, J. 2008. Inflation in South Africa: 1921 to 2006: History, measurement and credibility. $\mathrm{PhD}$ diss., University of KwaZulu-Natal.

Rossouw, J., and V. Padayachee. 2008. An analysis of inflation from a central banking perspective: The South African experience since 1921. Working Paper No 50, School of Development Studies, University of KwaZulu-Natal.

Rupert, A. 1974. Inflasie: hoe tem ons openbare vyand nommer een. Private publikasie met kopiereg. ISBN 0620014431.

SA Reserve Bank. n.d. Factors leading to the establishment of the South African Reserve Bank. Fact sheet No 6. Pretoria: SA Reserve Bank.

SA Reserve Bank. 1971. A short historical review issued in commemoration of the Bank's fiftieth anniversary. Pretoria: SA Reserve Bank.

SA Reserve Bank. 1984. Quarterly Bulletin. December. Pretoria.

SA Reserve Bank Act. 1944. No 29 of 1944, as amended, and the regulations framed in terms of Section 23 of the Act.

SA Reserve Bank Act. 1989. No 90 of 1989, as amended, and the regulations framed in terms of Section 36 of the Act.

SA Reserwebank. 1985. Jaarlikse Ekonomiese Verslag. Augustus. SA Reserve Bank: Pretoria. 
Samuels, L.H. 1967. Control of inflation. South African Journal of Economics 35, no. 4: 341356.

Samuelson, P.A., and R.M. Solow. 1960. Analytical aspects of anti-inflation policy. American Economic Review 50, no. 2: 177-194.

Sloman, J. 1994. Economics. 2nd ed. Harvester Wheatsheaf.

Stals, C.L. 1989. Governor's address, address at the 69th ordinary general meeting of shareholders, 29 August.

Stals, C.L. 1996. Seventy-five years of central banking in South Africa, address at the Governor of the South African Reserve Bank at the 75th anniversary banquet of the South African Reserve Bank, Pretoria. Available at: www.resbank.co.za

Statistics SA. Stats Online, www.statssa.gov.za/MoreIndicators/CPI/CPIHistory.pdf

Statistics SA. 2008. Consumer Price Index (CPI) - weights (total country). P0141.5. Available at www.statssa.gov.za

Tambo, O.R. 1985. Response to P.W. Botha's Rubicon speech. ANC press statement, 16 August, Lusaka. Available at www.nelsonmandela.org

Van der Horst, S. 1967. First discussant of a paper by W.F.J. Steenkamp, Productivity and inflation in South Africa. South African Journal of Economics 35, no. 4: 323-324.

Van der Merwe, E.J. 1997. Discussion paper on monetary policy operating procedures. Pretoria: SA Reserve Bank, October.

Van der Merwe, E.J. 1999. Monetary policy operating procedures in emerging-market economies. BIS Policy Papers No 5. March 1999. Switzerland: Bank for International Settlements.

Van der Merwe, E.J. 2004. Inflation targeting in South Africa. Occasional Paper No 19. Pretoria: SA Reserve Bank, July. Available online at: www.reservebank.co.za

Van Rensburg, C. 2003. The South African coin and banknote collection. South Africa: Randburg Coin. Randburg: South Africa. 


\section{APPENDICES}

\section{Appendix A}

Table A1: South African annual inflation rate measured as changes in CPI 1921 to 2010

\begin{tabular}{|c|c|c|c|c|c|c|c|}
\hline 1921 & -9.5 & 1944 & 3.5 & 1967 & 3.5 & 1990 & 14.4 \\
\hline 1922 & -16.6 & 1945 & 2.7 & 1968 & 1.8 & 1991 & 15.3 \\
\hline 1923 & -3.0 & 1946 & 1.5 & 1969 & 2.9 & 1992 & 13.9 \\
\hline 1924 & 1.4 & 1947 & 4.0 & 1970 & 4.1 & 1993 & 9.7 \\
\hline 1925 & -0.4 & 1948 & 5.6 & 1971 & 5.7 & 1994 & 9.0 \\
\hline 1926 & -1.5 & 1949 & 3.7 & 1972 & 6.1 & 1995 & 8.7 \\
\hline 1927 & 0.6 & 1950 & 4.0 & 1973 & 9.4 & 1996 & 7.4 \\
\hline 1928 & 0.0 & 1951 & 7.4 & 1974 & 11.6 & 1997 & 8.6 \\
\hline 1929 & -0.3 & 1952 & 8.7 & 1975 & 12.5 & 1998 & 6.9 \\
\hline 1930 & -2.3 & 1953 & 3.4 & 1976 & 11.2 & 1999 & 5.2 \\
\hline 1931 & -3.8 & 1954 & 1.6 & 1977 & 11.2 & 2000 & 5.4 \\
\hline 1932 & -4.5 & 1955 & 3.2 & 1978 & 11.0 & 2001 & 5.7 \\
\hline 1933 & -2.7 & 1956 & 1.9 & 1979 & 13.2 & 2002 & 9.2 \\
\hline 1934 & 1.2 & 1957 & 3.0 & 1980 & 13.8 & 2003 & 5.8 \\
\hline 1935 & -0.6 & 1958 & 3.5 & 1981 & 15.2 & 2004 & 1.4 \\
\hline 1936 & 0.3 & 1959 & 1.1 & 1982 & 14.7 & 2005 & 3.4 \\
\hline 1937 & 2.4 & 1960 & 1.2 & 1983 & 12.4 & 2006 & 4.7 \\
\hline 1938 & 3.6 & 1961 & 2.2 & 1984 & 11.5 & 2007 & 7.1 \\
\hline 1939 & 0.0 & 1962 & 1.3 & 1985 & 16.3 & 2008 & 11.5 \\
\hline 1940 & 3.3 & 1963 & 1.4 & 1986 & 18.6 & 2009 & 7.1 \\
\hline 1941 & 4.6 & 1964 & 2.6 & 1987 & 16.1 & 2010 & 4.3 \\
\hline 1942 & 8.4 & 1965 & 3.9 & 1988 & 12.9 & & \\
\hline 1943 & 6.0 & 1966 & 3.6 & 1989 & 14.7 & & \\
\hline
\end{tabular}

Source: Statistics SA n.d. 
Jannie Rossouw and Vishnu Padayachee

\section{Appendix B}

Table B1: South African CPI $1922=100$

\begin{tabular}{|c|c|c|c|c|c|c|c|}
\hline 1921 & 110.5 & 1944 & 117.1 & 1967 & 244.5 & 1990 & 2876.4 \\
\hline 1922 & 100.0 & 1945 & 120.1 & 1968 & 249.4 & 1991 & 3317.5 \\
\hline 1923 & 97.0 & 1946 & 121.9 & 1969 & 257.5 & 1992 & 3777.8 \\
\hline 1924 & 98.4 & 1947 & 126.9 & 1970 & 268.0 & 1993 & 4144.9 \\
\hline 1925 & 98.0 & 1948 & 134.2 & 1971 & 283.2 & 1994 & 4515.4 \\
\hline 1926 & 96.5 & 1949 & 139.2 & 1972 & 301.6 & 1995 & 4907.4 \\
\hline 1927 & 97.0 & 1950 & 144.7 & 1973 & 330.5 & 1996 & 5268.3 \\
\hline 1928 & 97.2 & 1951 & 155.4 & 1974 & 368.8 & 1997 & 5721.2 \\
\hline 1929 & 96.8 & 1952 & 168.9 & 1975 & 415.1 & 1998 & 6114.9 \\
\hline 1930 & 94.6 & 1953 & 174.8 & 1976 & 460.9 & 1999 & 6431.7 \\
\hline 1931 & 91.1 & 1954 & 178.0 & 1977 & 512.3 & 2000 & 6775.1 \\
\hline 1932 & 87.0 & 1955 & 183.6 & 1978 & 569.3 & 2001 & 7161.4 \\
\hline 1933 & 84.7 & 1956 & 187.1 & 1979 & 645.0 & 2002 & 7817.7 \\
\hline 1934 & 85.9 & 1957 & 192.7 & 1980 & 733.1 & 2003 & 8275.7 \\
\hline 1935 & 85.4 & 1958 & 199.4 & 1981 & 844.9 & 2004 & 8390.4 \\
\hline 1936 & 85.6 & 1959 & 201.7 & 1982 & 968.6 & 2005 & 8675.7 \\
\hline 1937 & 87.7 & 1960 & 204.1 & 1983 & 1087.8 & 2006 & 9083.5 \\
\hline 1938 & 90.9 & 1961 & 208.5 & 1984 & 1213.1 & 2007 & 9728.4 \\
\hline 1939 & 90.8 & 1962 & 211.2 & 1985 & 1410.8 & 2008 & 10847.2 \\
\hline 1940 & 94.0 & 1963 & 213.9 & 1986 & 1674.0 & 2009 & 11617.4 \\
\hline 1941 & 98.3 & 1964 & 219.4 & 1987 & 1944.5 & 2010 & 12170.6 \\
\hline 1942 & 106.5 & 1965 & 228.1 & 1988 & 2193.0 & & \\
\hline 1943 & 113.0 & 1966 & 236.3 & 1989 & 2516.1 & & \\
\hline
\end{tabular}

Sources: Statistics SA n.d. 